$06.5 ; 08.2$

\title{
Выглаживание поверхности антимонида галлия
}

\author{
(ㄱ Р.В. Левин, И.В. Федоров, А.С. Власов, П.Н. Брунков, Б.В. Пушный \\ Физико-технический институт им. А.Ф. Иофффе РАН, Санкт-Петербург, Россия \\ E-mail: Lev@vpegroup.ioffe.ru
}

Поступило в Редакцию 9 июля 2019г.

В окончательной редакции 25 августа 2020 г.

Принято к публикации 3 сентября 2020 г.

\begin{abstract}
Впервые представлены результаты исследования условий получения атомарно-гладкой поверхности подложек GaSb. Экспериментально показано, что можно улучшить качество поверхности образцов, изменяя условия отжига. Наименьшая шероховатость $1.3 \mathrm{~nm}$ получена при времени отжига $16 \mathrm{~min}$ при температуре $650^{\circ} \mathrm{C}$ в потоке триметилсурьмы и $\mathrm{H}_{2}$.
\end{abstract}

Ключевые слова: отжиг, подложка, $\mathrm{GaSb}$, шероховатость, атомно-силовой микроскоп, фотолюминесценция.

DOI: 10.21883/PJTF.2020.23.50350.17971

В последнее время все больше исследователей уделяет внимание квантово-размерным гетероструктурам. Эти материалы потенциально применимы для разработки многих перспективных устройств, таких как лазеры, фотодиоды и многие другие [1-3]. Свойства большинства полупроводниковых материалов чувствительны к качеству ростовых поверхностей (шероховатости). Одним из направлений, которое способствует созданию качественных квантово-размерных гетероструктур, является получение ростовых поверхностей, которые будут максимально приближены к атомарно-гладким поверхностям с наименьшей шероховатостью. Во время роста гетероструктур шероховатость ростовой поверхности может наследоваться от слоя к слою [4], что может привести к рассеянию носителей заряда [5] на гетерогранице с большой шероховатостью и, следовательно, к ухудшению параметров приборов на основе таких материалов. Также шероховатость влияет на величину переходных слоев в квантово-размерных гетероструктурах, что было представлено на примере напряженных сверхрешеток InAs/GaSb.

B настоящей работе методом атомно-силовой микроскопии (ACM) исследовалась зависимость шероховатости поверхности подложек $\mathrm{GaSb}$ от температуры, времени отжига и состава газовой среды, в которой проводился отжиг. Под термином „шероховатость“ в работе понимается среднеквадратичная шероховатость $R_{q}$, которая характеризует среднеквадратичное отклонение профиля поверхности относительно базовой линии внутри исследуемого участка.

Эксперименты проводились на установке газофазной эпитаксии AIX200 (AIXTRON, Германия) на подложках $n$ - $\mathrm{GaSb}(001)$ с уровнем легирования $n=(5-7) \cdot 10^{17} \mathrm{~cm}^{-3}$. Давление в реакторе составляло 76 Torr. Подложка во время роста вращалась со скоростью более $100 \mathrm{rpm}$. Газ-носитель - очищенный водород с точкой росы не выше $-100^{\circ} \mathrm{C}$, а суммарный поток через реактор составлял $5.5 \mathrm{slpm}$. Среднеквадратичная шероховатость подложек перед отжигом составляла
$R_{q}=20 \mathrm{~nm}$. На начальном этапе исследований подложки отжигались в температурном диапазоне $T=500-700^{\circ} \mathrm{C}$ в течение $2 \mathrm{~min}$ в потоке водорода. На следующем этапе исследовалось влияние времени отжига и состава газовой среды (образцы отжигались в потоке водорода или в смешанном газовом потоке водорода и триметилсурьмы $(\mathrm{TMSb}))$ на морфологию поверхности подложек при оптимальной температуре отжига. Шероховатость всех образцов исследовалась на атомно-силовом микроскопе Dimension 3100 (Vecco, CША). Для измерения топографии поверхности использовался кантилевер TESP-V2 с радиусом кривизны острия $8 \mathrm{~nm}$ [6].

На первом этапе определялась оптимальная температура отжига, т.е. температура, при которой наблюдалась наименьшая шероховатость. Для этого образцы подложек отжигались в течение 2 min при различных температурах в диапазоне $T=500-700^{\circ} \mathrm{C}$ в потоке водорода. После отжига образцы были исследованы на ACM. Анализ данных с АCM показал, что наименьшая

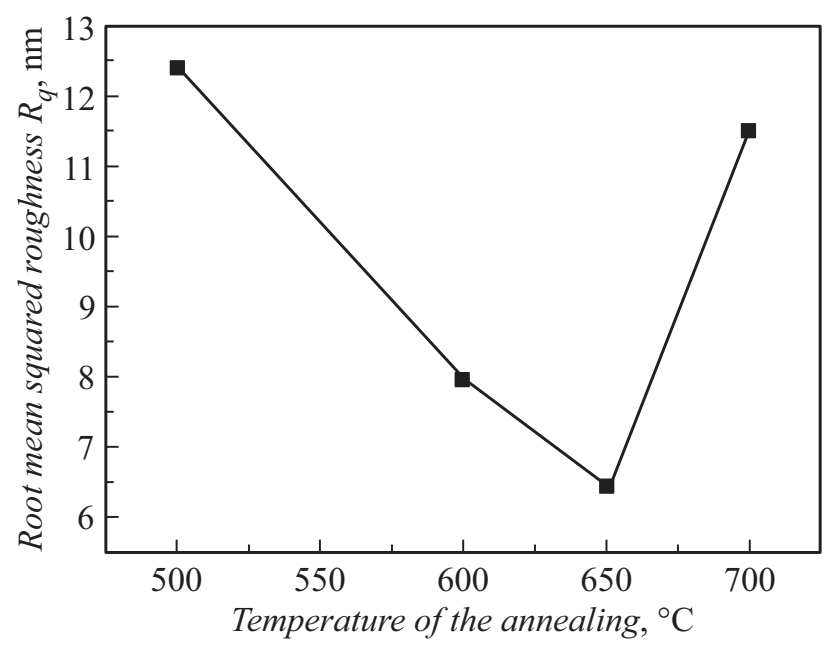

Рис. 1. Зависимости шероховатости поверхности образцов от температуры отжига в потоке $\mathrm{H}_{2}$. 


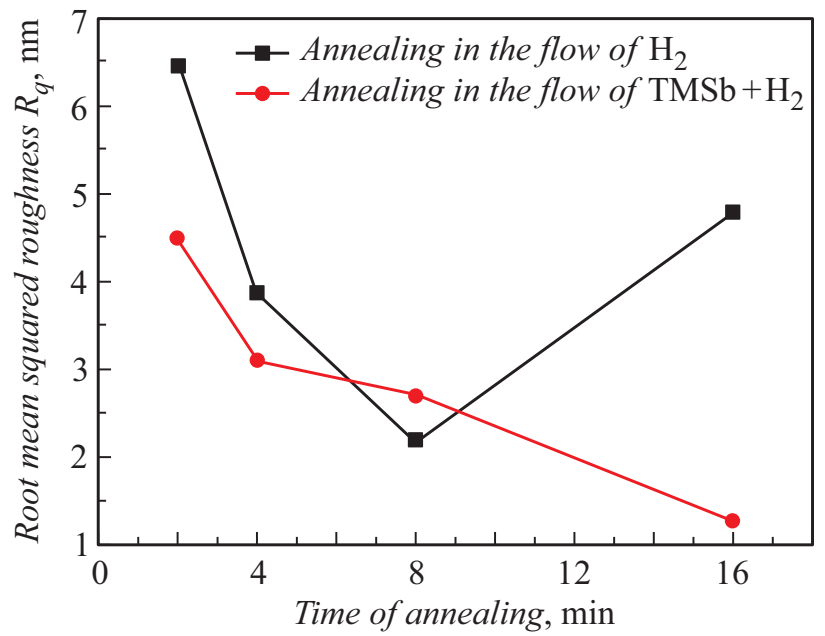

Рис. 2. Зависимость шероховатости поверхности образцов от времени в различных газовых средах $\left(T=650^{\circ} \mathrm{C}\right)$.

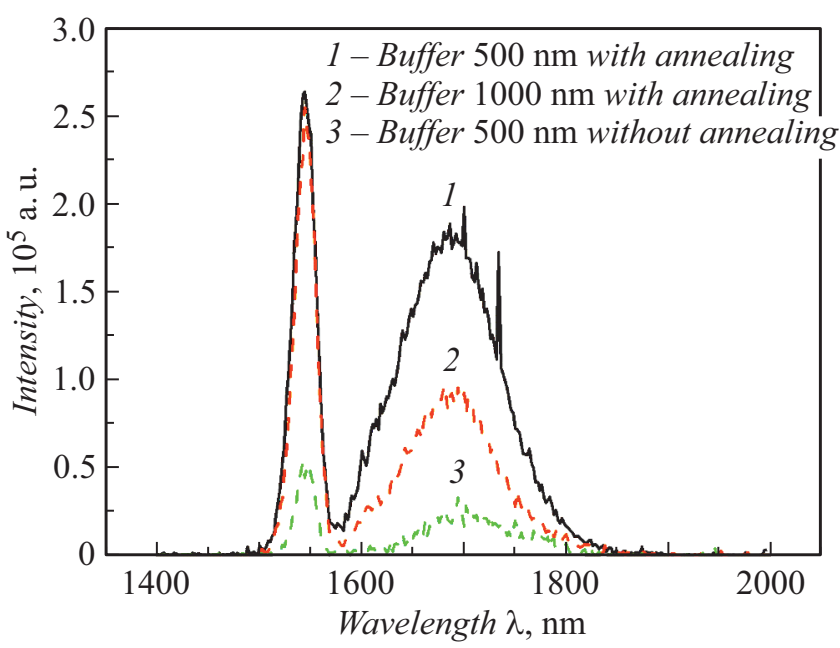

Рис. 3. Спектры фотолюминесценции выращенных буферных слоев толщиной 500 и $1000 \mathrm{~nm}$ с отжигом и без него.

шероховатость достигается при температуре $650^{\circ} \mathrm{C}$ и составляет $6.4 \mathrm{~nm}$ (рис. 1).

Полученную зависимость мы связываем с одновременной десорбцией атомов $\mathrm{Ga}$ и $\mathrm{Sb}$ с поверхности подложки во время отжига.

Согласно [7], до $600^{\circ} \mathrm{C}$ давления паров галлия над подложкой больше, чем у сурьмы; следовательно, он активнее десорбирует с поверхности отжигаемой подложки, получается более развитый рельеф. При приближении к температуре $600^{\circ} \mathrm{C}$ давления паров $\mathrm{Ga}$ и $\mathrm{Sb}$ достигают паритета, идет более равномерная десорбция атомов с подложки, из-за чего поверхность подложки приобретает меньшую величину шероховатости. Если продолжать увеличивать температуру, то будет активнее десорбировать сурьма, что снова увеличит шероховатость подложки.
После определения оптимальной температуры $\left(650^{\circ} \mathrm{C}\right)$ исследовалось влияние времени отжига и различной газовой среды на морфологию поверхности образцов. Для этого подложки отжигались в течение времени $t=2-16 \min$ в потоке водорода или смешанном потоке водорода и $\mathrm{TMSb}$ (скорость подачи $\mathrm{TMSb}$ в реактор примерно $15 \mu \mathrm{mol} / \mathrm{min})$. На рис. 2 представлены результаты, полученные после анализа данных АCM.

Для отжига в потоке водорода наименышая шероховатость $2.2 \mathrm{~nm}$ достигается на 8-й минуте, при дальнейшем увеличении времени отжига шероховатость увеличивается. Для отжига в потоке TMSb и $\mathrm{H}_{2}$ наименьшая шероховатость $1.3 \mathrm{~nm}$ достигалась на 16-й минуте, причем это наименьшая полученная шероховатость.

Методом фотолюминесценции было исследовано влияние отжига на люминесцентные свойства слоев. Для этого были выращены буферные слои толщиной 500 и $1000 \mathrm{~nm}$ при температуре $600^{\circ} \mathrm{C}$ и соотношении элементов V/III, равном 2, аналогично режиму из работы [8]. Перед ростом буферных слоев все подложки отжигались при $650^{\circ} \mathrm{C}$ в течение $2 \mathrm{~min}$. Первоначальная шероховатость поверхности подложек GaSb была $20 \mathrm{~nm}$, а после первого отжига - $6.4 \mathrm{~nm}$. После роста буферного слоя шероховатость составила $3.8 \mathrm{~nm}$. Затем образцы с выращенными буферными слоями отжигались при $650^{\circ} \mathrm{C}$ в течение $2 \mathrm{~min}$. Шероховатость слоев после отжига составила $2.1 \mathrm{~nm}$. Анализ спектров фотолюминесценции (рис. 3) показал, что даже отжиг в течение $2 \mathrm{~min}$ улучшает качество поверхности выращенных структур и способствует увеличению интенсивности излучения примерно в 5 раз (по сравнению с неотожженным буферным слоем). Независимо от толщины выращенного буферного слоя величина интенсивности основного (межзонного) пика не изменяется у отожженных образцов.

В результате исследований было показано, что оптимальная температура отжига подложек $\mathrm{GaSb}$ равна $650^{\circ} \mathrm{C}$. Наименьшая шероховатость при отжиге в потоке водорода была $2.2 \mathrm{~nm}$ при времени отжига $8 \mathrm{~min}$, а в потоке $\mathrm{TMSb}$ и $\mathrm{H}_{2}-1.3 \mathrm{~nm}$ при времени отжига $16 \mathrm{~min}$. Также было показано, что даже небольшой отжиг благоприятно сказывается на люминесцентных свойствах выращенных слоев.

\section{Финансирование работы}

АСМ-исследования проводились с использованием оборудования ЦКП „Материаловедение и диагностика в передовых технологиях“ (ФТИ им. А.Ф. Иоффе), поддерживаемого Минобрнауки России (уникальный идентификатор проекта RFMEFI62117X0018).

\section{Конфликт интересов}

Авторы заявляют, что у них нет конфликта интересов. 


\section{Список литературы}

[1] Razeghi M., Nguyen B.-M. // Rep. Prog. Phys. 2014. V. 77. P. 082401-082418.

[2] Rogalski A., Kopytko M., Martyniuk P. // Proc. SPIE. 2017. V. 10177. P. 1017715.

[3] Li X., Zhao Y., Wu Q., Teng Y., Hao X., Huang Y. // J. Cryst. Growth. 2018. V. 502. P. 71-75.

[4] Васев А.В., Путято М.А., Семягин Б.Р. // Вестн. НГУ. Сер.: Физика. 2008. Т. 3. № 4. С. 9-19.

[5] Протасов Д.Ю., Малин Т.В., Тихонов А.В., Цачульников А.Ф., Журавлев К.С. // ФТП. 2013. Т. 47. В. 1. С. 36-47.

[6] www.brukerafmprobes.com

[7] Optoelectronic properties of semiconductors and superlattices. V. 3. Antimonide-related strained-layer heterostructures / Ed. M.O. Manasreh. 1st ed. CRC Press, 1997. 501 p.

[8] Левин Р.В., Неведомский В.Н., Баженов Н.Л., Зегря Г.Г., Пушный Б.В., Мизеров М.Н. // ФТП. 2019. Т. 53. В. 2. C. 273-276. 